\title{
IMPLEMENTASI BUDAYA LITERASI PADA KEMANDIRIAN PESERTA DIDIK DI SD MUHAMMADIYAH SERUT BANTUL
}

\author{
Desy Ika Ratna Furi ${ }^{1}$, Sugeng Riyanto ${ }^{2}$ \\ PGSD, FKIP, Universitas Ahmad Dahlan \\ Pos el : desyika312@gmail.com
}

\begin{abstract}
Literacy culture needs to be instilled early on, because it can foster students' interest in reading. Serut Muhammadiyah Elementary School is one of the schools implementing a literacy culture program. This study aims to explain the planning, implementation, evaluation of literacy culture programs at SD Muhammadiyah Serut, as well as describing the independence of students in literacy culture at SD Muhammadiyah Serut. This type of research uses descriptive research with a qualitative approach. The research subjects were school principals, class III teachers and class IV teachers, librarians, class III and IV students taken randomly. The objects in this study are all matters relating to the independence of students in literacy culture in SD Muhammadiyah Serut. Data collection techniques used include observation, interviews, and documentation. Data were analyzed using the Miles and Huberman models, while to test the validity of the data using source triangulation and technique triangulation. The results showed: that literacy program planning is related to the vision, mission and goals of the library, while the literacy culture has been running smoothly. Literacy cultural activities include reading iqra, reading Juz 'Amma, reading activities 15 minutes before the lesson begins, short story activities and bulletin classes. The next stage is the evaluation at Serut Muhammadiyah Elementary School conducted once a semester, to find out the extent of the literacy culture program. In the independence of students in the culture of literacy at Serut Muhammadiyah Elementary School as students do not read when the teacher does not ask. Then students are not confident when reading the results of their work.
\end{abstract}

Keywords: Literacy, Literacy Culture, Independence

\begin{abstract}
ABSTRAK
Budaya literasi perlu ditanamkan sejak dini, karena dapat menumbuhkan minat baca peserta didik. SD Muhammadiyah Serut merupakan salah satu sekolah yang menerapkan program budaya literasi. Penelitian ini bertujuan untuk menjelaskan perencanaan, pelaksanaan, evaluasi pada program budaya literasi di SD Muhammadiyah Serut, serta mendeskripsikan kemandirian peserta didik pada budaya literasi di SD
\end{abstract}


Muhammadiyah Serut. Jenis penelitian ini menggunakan penelitian deskriptif dengan pendekatan kualitatif. Subjek penelitiannya adalah kepala sekolah, guru kelas III dan guru kelas IV, pustakawan, peserta didik kelas III dan IV yang diambil secara acak. Objek dalam penelitian ini adalah segala hal yang berkaitan dengan kemandirian peserta didik pada budaya literasi di SD Muhammadiyah Serut. Teknik pengumpulan data yang digunakan meliputi observasi, wawancara, dan dokumentasi. Data dianalisis menggunakan model Miles dan Huberman, sedangkan untuk menguji keabsahan data menggunakan trianggulasi sumber dan trianggulasi teknik. Hasil penelitian menunjukan: bahwa perencanaan program literasi berkaitan dengan visi, misi dan tujuan perpustakaan, sedangkan pelaksanaan budaya literasi sudah berjalan dengan lancar. Kegiatan budaya literasi meliputi membaca iqra, membaca Juz'Amma, membaca kegiatan 15 menit sebelum pelajaran dimulai, kegiatan kelas cerpen dan kelas buletin. Tahap selanjutnya yaitu evaluasi di SD Muhammadiyah Serut dilakukan setiap satu semester sekali, untuk mengetahui sejauh mana program budaya literasi berjalan. Dalam kemandirian peserta didik pada budaya literasi di SD Muhammadiyah Serut seperti halnya peserta didik tidak membaca ketika guru tidak memintanya. Kemudian peserta didik belum percaya diri ketika membacakan hasil pekerjaannya.

Kata kunci :Literasi, Budaya Literasi, Kemandirian

\section{PENDAHULUAN}

Literasi adalah kemampuan mengakses, memahami, dan menggunakan sesuatu secara cerdas melalui berbagai aktivitas, meliputi membaca, menulis, menyimak, melihat dan berbicara (Kemendikbud, 2016: 2). Literasi sebenarnya dapat dibangun dari diri sendiri melalui kebiasaan, karena terbiasa membaca dan menulis bukanlah bawaan dari lahir akan tetapi dibangun dari rutinitas, sehingga akan menjadi kebiasaan yang melekat pada diri peserta didik. Namun membaca bagi kebanyakan peserta didik tidak menyukainya karena merupakan kegiatan yang membosankan padahal banyak manfaat yang bisa kita dapatkan dari membaca. Manfaat membaca selain menambah wawasaan dan pengetahuan yaitu dapat menggali bakat dan potensi yang dimilikinya, dapat melatih daya berpikir, melatih konsentrasi dan meningkatkan prestasi di sekolah.

Sekolah mempunyai peran penting dalam meningkatkan program literasi sehingga banyak anggapan mengenai program literasi sekolah tidak bisa sepenuhnya membantu meningkatkan budaya literasi pada peserta didik. Hal ini juga disebakan karena sarana dan prasarana yang kurang mendukung dalam program literasi. Berdasarkan observasi tanggal 22 April 2019 di perpustakaan SD Muhammadiyah Serut tidak hanya digunakan untuk membaca saja, tetapi juga digunakan untuk tempat ibadah solat. Disebabkan banyaknya peserta didik tetapi ruangan yang tidak memadahi. Selain itu, kurangnya kemandirian peserta didik pada budaya literasi. Hal ini tampak ketika guru meminta membaca buku namun peserta didik ada yang berlarian di dalam kelas. Menurut Mustari (2015: 108) 
peserta didik adalah orang/individu yang mendapat pelayanan pendidikan sesuai dengan minat, bakat dan kemampuan agar tumbuh dan berkembang dengan baik serta mempunyai kepuasaan dalam menerima pelajaran yang diberikan oleh

pendidiknya. Dalam proses pembelajaran peserta didik ingin meraih cita-cita dan memiliki tujuan sehingga dalam mencapainya perlu mengoptimalkan proses belajarnya. Proses belajar mengajar faktor pertama kali yang harus diperhatikan adalah peserta didik. Karena setiap peserta didik mempunyai karakteristik yang berbeda-beda. Guru mengarahkan peserta didik untuk lebih mandiri. Untuk menjadi peserta didik yang mandiri memerlukan proses dari belajar dan pengalaman. Menurut Desmita (2016: 185) kemandirian atau otonom merupakan kemampuan untuk mengendalikan dan mengatur pikiran, perasaan dan tidakan sendiri secara bebas serta berusaha sendiri untuk mengatasi perasaan-perasaan malu dan keragu-raguan. Dalam perkembangan kemandirian peserta didik dapat ditentukan ketika individu mampu menyelesaikan tugasnya tanpa pengaruh atau ajakan dari orang lain. Faktor keberhasilan belajar peserta didik dapat ditentukan dengan kemandirian peserta didik. Sehingga untuk meraih kesuksesan di sekolah peserta didik bisa menerapkan sikap mandiri. Karena sikap mandiri penting dimiliki oleh siapa pun.

Budaya literasi sering dikenal dengan budaya membaca atau menulis untuk dapat menambah informasi, sedangkan literasi sekolah dalam konteks Gerakan Literasi Sekolah (GLS) adalah kemampuan mengakses, memahami, dan menggunakan sesuatu secara cerdas melalui berbagai aktivitas, antara lain membaca, melihat, menyimak, menulis, dan berbicara (Kemendikbud, 2016: 2). Dalam budaya literasi sekolah peserta didik diminta membiasakan membaca buku selama 15 menit sebelum jam pelajaran dimulai. Pembiasaan membaca buku dapat menambah wawasan dan pengetahuan yang luas bagi peserta didik. Peserta didik dalam budaya literasi dituntut untuk berfikir secara kritis sesuai dengan tahap dan komponen literasi. Menurut Kemendikbud (2016: 8) komponen literasi meliputi literasi dini (Early Literacy), literasi dasar (Basic Literacy), literasi perpustakaan (Library Literacy), literasi media (Media Literacy), literasi teknologi (Technology Literacy), literasi visual (Visual Literacy). Keenam komponen tersebut saling berkaitan satu dengan yang lain. Komponen literasi dapat dikembangkan untuk mencipkan lingkungan literasi di sekolah. Dalam menciptakan lingkungan literasi di sekolah yang baik, dapat menunjang keberhasilan penerapan pendidikan berbasis literasi.

Berdasarkan hasil observasi dan wawancara pada tanggal 22-25 April 2019 di SD Muhammadiyah Serut Bantul, terdapat beberapa permasalahan antara lain; Pertama, sebagian peserta didik tidak mampu menyelesaikan tugasnya sendiri dan tidak mampu mengatasi masalah belajarnya sendiri serta masih banyak peserta didik yang tidak percaya diri. Hal itu tampak pada pengamatan di kelas bahwa kemampuan peserta didik antara yang satu dengan yang lain berbeda-beda, ada peserta didik yang memiliki kepercayaan diri yang tinggi ada juga yang tidak, ada juga yang tidak bisa menyelesaikan tugasnya sendiri, selain itu tidak berani bertanya apabila menghadapi kesulitan dalam belajar. Kedua, peserta didik kurang mengetahui manfaat membaca. Hal ini tampak 
ketika guru meminta peserta didik untuk membaca, setelah itu guru keluar sebentar karena ada keperluan, kemudian peserta didik diberi tugas untuk membaca. Namun ada beberapa peserta didik yang tidak membaca, bahkan ada yang asyik bermain dengan temannya. Ada pula peserta didik yang sering berpura-pura ijin ke WC, padahal sebenarnya hanya tidak ingin mengikuti pelajaran. Ketiga, minimnya buku bacaan di perpustakaan. Hal ini tampak ketika peserta didik di perpustakaan pada waktu istirahat, peserta didik hanya bermain, bahkan ada peserta didik yang hanya membuka buku melihat gambar-gambar yang ada dibuku, karena bukunya hanya itu-itu saja. Minimnya buku bacaan dapat menyebabkan kurang tertarik mengunjungi perpustakaan. Karena buku bacaan yang menarik dan selalu ada buku yang terbaru dapat membuat peserta didik tertarik mengunjungi perpustakaan. Keempat, di perpustakaan terkadang dibuat untuk salat dhuha dan salat dhuhur karena banyaknya peserta didik namun sarana kurang memadai. Sarana yang kurang memadai menyebabkan peserta didik kurang tertarik ke perpustakaan. Perpustakaan yang tertata rapi, dan membuat nyaman peserta didik untuk membaca, dapat membuat peserta didik tidak bosan dan dapat mengunjungi perpustakaan terus-menerus.

Berdasarkan masalah-masalah tersebut menunjukkan kemandirian peserta didik pada budaya literasi belum tumbuh pada diri peserta didik. Oleh karena itu, kemandirian peserta didik pada budaya literasi perlu ditanamkan sejak dini. Dengan bekal mandiri peserta didik dapat meraih kesuksesan di sekolah. Salah satu sekolah yang sudah menerapkan budaya literasi adalah SD Muhammadiyah Serut Bantul. Beberapa contoh yang dapat dilihat dari obervasi pada tanggal 23 April 2019 yaitu adanya kegiatan 15 menit sebelum pelajaran dimulai, kegiatan membaca iqra, kegiatan membaca juz'ama. Berdasarkan latarbelakang tersebut penulis tertarik untuk mengetahui bagaimana upaya sekolah pada implementasi budaya literasi di SD Muhammadiyah Serut. Penulis memutuskan untuk melakukan penelitian yang berlokasi di SD Muhammadiyah Serut Bantul di karenakan sekolah tersebut mendukung untuk melakukan penelitian tentang budaya literasi. Budaya literasi sudah diterapkan di SD Muhammadiyah Serut Bantul. Dari hasil observasi pada bulan April 2019, SD Muhammadiyah Serut sangat mengupayakan implementasi budaya literasi. Selain itu juga terlihat jelas bahwa SD Muhammadiyah Serut sudah menerbitkan satu buku yang berjudul 'Melukis Langit Impian'.

\section{METODE PENELITIAN}

Penelitian ini menggunakan pendekatan kualitatif. Penelitian ini termasuk jenispenelitian deskriptif yang bertujuan untuk membuat deskripsi, gambaran atau lukisan secara sistematis, faktual dan akurat mengenai fakta-fakta, sifat-sifat serta hubungan antar fenomena yang diteliti. Data yang dikumpulkan lebih berupa kata-kata atau gambaran mengenai implementasi budaya literasi pada kemandirian peserta didik di SD Muhammadiyah Serut Bantul.

Penelitian ini dilakukan di SD Muhammadiyah Serut Bantul. Subjek penelitian ini adalah kepala sekolah, pustakawan, guru kelas III, guru kelas IV dan peserta didik kelas III, peserta didik kelas IV yang diambil secara acak. Objek penelitian ini adalah 
implementasi budaya literasi pada kemandirian peserta didik di SD Muhammadiyah Serut Bantul. Teknik pengumpulan data menggunakan observasi, wawancara, dan dokumentasi. Teknik pengumpulan data ini bertujuan untuk mengetahui perencanaan, pelaksanaa, evaluasi program budaya literasi di SD Muhammadiyah Serut. Instrumen pengumpulan data menggunakan lembar observasi, pedoman wawancara, dan pedoman dokumentasi. Teknik analisis data menggunakan triangulasi sumber dan triangulasi teknik.

\section{HASIL DAN PEMBAHASAN}

Penelitian yang dilakukan di SD Muhammadiyah Serut mengenai "Implementaasi Budaya Literasi pada Kemandirian Peserta didik di SD Muhammadiyah Serut". Penelitian ini dilakukan mulai tanggal 03-18 September 2019. Data yang diperoleh dalam penelitian ini berasal dari wawancara, observasi, dokumentasi. Subjek penelitiannya adalah kepala sekolah, guru kelas 3 dan guru kelas 4, peserta didik kelas 3 dan kelas 4 yang diambil secara acak, pustakawan. Proses pengambilan data dimulai dari proses observasi dan kemudian dilanjutkan wawancara dan dokumentasi yang berasal dari sekolah. Dokumentasi yang berasal dari sekolah berisikan data-data dokumentasi sekolah. Setelah proses pengambilan data tersebut dengan triangulasi teknik dan triangulasi sumber kemudian dilakukan reduksi data dan penerikan kesimpulan. Berdasarkan hasil penelitian yang didapat mengenai implementasi budaya literasi pada kemandirian peserta didik di SD Muhammadiyah Serut Bantul:

1. Perencanaan, pelaksaanaan, evaluasi program budaya literasi di SD Muhammadiyah Serut.

Perencanaan program budaya literasi merupakan hal penting bagi SD Muhmmadiyah Serut sebagai langkah awal dalam menanamkan membaca buku sejak dini. Rencana yang dibuat di SD Muhammadiyah Serut dalam mengimplementasikan budaya literasi dilihat dari kebijakan program literasi yang meliputi adanya visi, misi program literasi dan tujuan. Visi, misi dan tujuan berkaitan dengan mendayagunakan budaya tulisan, dalam berbagai kehidupan. Hal tersebut terbukti di SD Muhammadiyah Serut menerapkan budaya literasi sekolah. Visi misi tersebut digunakan sebagai acuan untuk membuat program budaya literasi di SD Muhammadiyah Serut. Dengan adanya rencana program yang berasal dari visi misi akan membuat program literasi lebih terarah dan terprogram dengan baik.

Pelaksanaan dalam budaya literasi di SD Muhammadiyah Serut berdasarkan rencana kegiatan dan program yang sudah diterapkan. Pelaksanaan tersebut berkaitan dengan kegiatan yang menerapkan budaya literasi seperti kegiatan 15 menit membaca sebelum pelajaran dimulai, kegiatan membaca juz'ama, kegiatan kelas cerpen dan kelas bulletin, kegiatan membaca iqra. Membaca buku selama 15 menit ini dilaksanakan di pagi hari setelah salat dhuha dan membaca Juz'Amma. Dalam kegiatan membaca Alqur'an di SD Muhammadiyah Serut terdapat kegiatan membaca Juz'Amma dan membaca iqra. Membaca Juz'Amma dilakukan setiap pagi setelah 
salat dhuha. Kegiatan membaca Juz'Amma dilakukan secara bersama-sama. Kegiatan tersebut dibimbing oleh guru kelas masing-masing. Kegiatan membaca iqra dilakukan setiap sore. Kegiatan tersebut dibimbing oleh 2 orang guru. Satu persatu peserta didik maju kedepan untuk membaca iqro maupun Alqur'an. Kemudian ada kegiatan membaca 15 menit. SD Muhammadiyah Serut telah melaksanakan kegiatan membaca selama 15 menit untuk kelas bawah dan untuk kelas atas selama 30 menit sebelum pelajaran dimulai. Kegiatan membaca setiap pagi sebelum pelajaran dimulai untuk kelas atas selama 30 menit. Peserta didik diberi kesempatan untuk membaca selama 15 menit kemudian guru meminta kepada peserta didik untuk menuliskan judul bacaan, tokoh dalam cerita tersebut, karakteristik, amanat, dan isi cerita tersebut. Setelah selesai mengerjakan salah satu peserta didik diminta untuk membacakan hasil pekerjaanya di ruang kelas.

Kegiatan kelas cerpen dan kelas buletin dilaksanakan di SD Muhammadiyah Serut setiap hari selasa pukul 13.30-15.00 WIB. Dalam kegiatan kelas buletin dan kelas cerpen peserta didik diseleksi agar dapat memaksimalkan cerpencerpen yang telah diterbitkan. Kumpulan cerpen di SD Muhammadiyah Serut sudah menerbitkan 1 kumpulan cerpen yang berjudul "Melukis Langit Impian". Dengan adanya hal tersebut dapat mengembangkan bakat peserta didik. Tidak hanya itu di SD Muhammadiayh Serut juga memanfaatkan perpustakaan sebagai sumber mencari ilmu. Pemanfaatan perpustakaan dan pemanfaatan sudut baca kelas untuk menunjang berjalannya program literasi.

Pelaksanaan program budaya literasi tentunya ada evaluasi pada saat proses kegiatan bertujuan untuk mengatasi permasalahan yang ada saat program tersebut diterapkan. Evaluasi tersebut berupa pertemuan setiap satu semester sekali. Hasil evaluasi tersebut digunakan untuk memperbaiki kekurangan dalam proses kegiatan penerapan budaya literasi di SD Muhammadiyah Serut sehingga hasilnya akan lebih baik lagi. Masukan dari guru di dalam rapat juga digunakan untuk evaluasi agar tingkat keberhasilan dalam penerapan budaya literasi semakin baik.

2. Kemandirian Peserta didik pada Budaya Literasi di SD Muhammadiyah Serut.

Kemandirian peserta didik pada budaya literasi di SD Muhammadiyah Serut seperti peserta didik jika tidak diminta untuk membaca peserta didik tidak membaca, kemudian peserta didik masih perlu bimbingan dari ibu guru. Terlihat ketika peserta didik diminta untuk menuliskan isi cerita peserta didik masih bertanya-tanya terus. Dalam kegiatan 15 menit membaca ada 10 peserta didik yang bermain dengan teman sebangkunya ada juga yang izin keluar wc, sebenarnya peserta didik tidak ke wc tetapi mereka hanya ingin keluar kelas saja. Hal tersebut membuktikan bahwa peserta didik belum memiliki motivasi untuk selalu membaca. Peserta didik juga belum mandiri, ketika guru meminta peserta didik untuk membacakan hasil pekerjaannya dari ringkasan yang dibaca, peserta didik tidak mau maju kedepan untuk membacakan hasil pekerjaannya. Peserta didik juga bisa mengembangkan 
pontensi yang dimiliki seperti menulis cerpen, sehingga dapat menghasilkan karya peserta didik.

\section{SIMPULAN}

Berdasarkan penelitian tentang implementasi budaya literasi pada kemandirian peserta didik di SD Muhammadiyah Serut.

1. Implementasi budaya literasi pada kemandirian peserta didik di SD Muhammadiyah Serut Bantul

Implementasi budaya literasi di SD Muhammadiyah Serut sudah berjalan dengan baik dan lancar. Kelancaran program tersebut tidak lepas dari mulainya perencanaan program budaya literasi. Pereencanaan program literasi berkaitan dengan visi misi dan tujuan perpustakaan. Kemudian menyusun program budaya literasi. Pelaksanaan program tersebut dengan melibatkan seluruh warga sekolah. Selanjutnya pelaksanaan budaya literasi dilakukan oleh seluruh peserta didik. Kegiatan pada pelaksanaan antara lain: kegiatan 15 menit membaca sebelum jam pelajaran dimulai, kegiatan membaca iqra, kegiatan membaca juz'ama, kegiatan kelas cerpen dan bulletin. Setelah pelaksanaan budaya literasi, tahap selanjunya yaitu evaluasi program budaya literasi di SD Muhammadiyah Serut. Evaluasi yaitu melakukan pertemuan satu semester sekali, untuk mengetahui sejauh mana program budaya literasi berjalan.

2. Kemandirian peserta didik pada budaya literasi di SD Muhammadiyah Serut

Kemandirian peserta didik pada budaya literasi di SD Muhammadiyah Serut seperti halnya peserta didik tidak membaca jika guru tidak meminta untuk membaca, peserta didik juga belum mempunyai motivasi sepunuhnya untuk selalu membaca buku, peserta didik belum percaya diri dalam membacakan hasil pekerjaannya. Hal itu terbukti ketika peserta didik diminta untuk membacakan hasil pekerjaannya, peserta didik tidak berani untuk maju. Indikator kemandirian peserta didik selain percaya diri dan memiliki motivasi gemar membaca, selain itu yaitu mengembangkan potensi yang dimiliki peserta didik.

\section{DAFTAR PUSTAKA}

Desmita. (2016). Psikologi Perkembangan Peserta Didik. Bandung: PT Remaja Rosdakarya.

Kemendikbud. (2016). Panduan Gerakan Literasi di Sekolah Dasar. Jakarta: Direktorat Jendral Pendidikan Dasar dan Menengah Kementerian Pendidikan dan Kebudayaan. 
Moleong.L.J. 2011. Metodologi Penelitian Kualitatif. Bandung. PT.Remaja Rosdakarya.

Mustari Mohammad. (2015). Manajemen Pendidikan. Jakarta: PT Raja Grafindo.

Wiendarti, Pangesti, dkk. (2016). Desain Induk Gerakan Literasi Sekolah. Jakarta: Direktorat Jendral Pendidikan Dasar dan Menengah Kementerian Pendidikan dan Kebudayaan. 